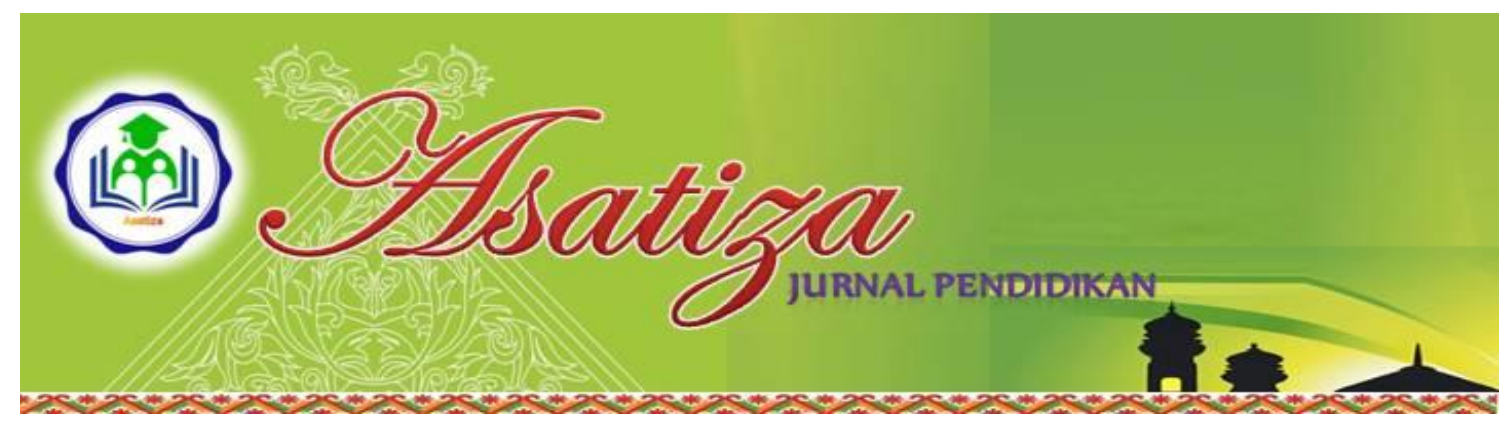

\title{
PENGARUH KOMUNIKASI DALAM PEMBELAJARAN TERHADAP HASIL BELAJAR KOGNITIF PADA MATA PELAJARAN SEJARAH KEBUDAYAAN ISLAM DI MADRASAH IBTIDAIYAH NURUL JIHAD KECAMATAN TEMBILAHAN HULU
}

\author{
Sepna Sari ${ }^{1}$ \\ ${ }^{1}$ STAI Auliaurrasyidin Tembilahan
}

\begin{abstract}
Abstrak
Permasalahan dalam penelitian ini dirumuskan sebagai berikut: Bagaimana pengaruh komunikasi dalam pembelajaran terhadap hasil belajar kognitif pada mata pelajaran Sejarah Kebudayaan Islam di Madrasah Ibtidaiyah Nurul Jihad Kecamatan Tembilahan Hulu?

Populasi dalam penelitian ini adalah 1 orang guru mata pelajaran Sejarah Kebudayaan Islam dan 130 orang siswa kelas tinggi, yaitu kelas IV, V, dan VI. Sedangkan sampel untuk siswa diambil sebanyak 20\%, yaitu $130 \times 120 \%=26$ orang siswa, dengan menggunakan jenis sampel random sampling. Data dalam penelitian ini dikumpulkan dengan menggunakan teknik observasi, dan dokumentasi. Selanjutnya data yang terkumpul dianalisa dengan menggunakan rumus uji t.

Dari hasil analisa data melalui observasi dapat disimpulkan bahwa Komunikasi dalam pembelajaran pada mata pelajaran Sejarah Kebudayaan Islam, mencapai angka $72,69 \%$ dan dikategorikan baik, karena angka 72,69\% terletak pada interval $61 \%-80 \%$. Hasil belajar kognitif siswa pada mata pelajaran Sejarah Kebudayaan Islam, mencapai angkai 50,32\%, dan dikategorikan cukup baik, karena angka 50,32\% terletak pada interval $61 \%$ - 80\%. Dari data melalui observasi terhadap variabel $\mathrm{X}$ dan $\mathrm{Y}$ dapat disimpulkan bahwa tidak terdapat pengaruh yang positif dan signifikan antara komunikasi dalam pembelajaran terhadap hasil belajar kognitif pada mata pelajaran Sejarah Kebudayaan Islam, yang ditunjukkan dengan angka 0,2 dan diinterpretasikan sangat rendah. Karena berdasarkan tabel t, nilai untuk 25 adalah 1,708. Sehingga thitung $\leq$ tabel, artinya $0,2 \leq 1,708$, maka Ho diterima, angka 0,2 terletak pada daerah penolakan, maka Ha ditolak dan Ho diterima.
\end{abstract}

Kata Kunci: Komunikasi, Hasil Belajar Kognitif.

\section{A. PENDAHULUAN}

\section{Latar Belakang}

Di era globalisasi ini, program pembelajaran belum dapat memberikan hasil yang memuaskan. Hal ini terlihat ketika proses pembelajaran berlangsung, suasana $\begin{array}{llr}\text { kelas nampak tegang } & \text { dan } \\ \text { membosankan. } & \text { Guru } & \text { sibuk }\end{array}$ menyampaikan materi tanpa mau tahu tentang siswanya paham atau tidak. Dalam penilaian terdapat penekanan pada ujian menilai hafalan, dari tingkat prasekolah sampai universitas. 
Hasilnya adalah para siswa dewasa ini tidak mampu berpikir sendiri, tidak mampu berbuat, dan tidak mampu memecahkan masalah-masalah. ${ }^{1}$

Oleh karena itu, untuk membantu siswa menumbuh kembangkan aspekaspek dirinya, maka perlu dikembangkan pembelajaran yang tidak hanya menekankan aspek ingatan, hafalan, (berbasis materi), namun sampai pada aspek penalaran dan kemampuan menggunakan keterampilan secara baik serta sifat berpikir yang aktif positif.

Ketidakefektifan komunikasi yang dilakukan oleh guru Sekolah Dasar di desa adalah sebagian besar murid di desa belum paham dengan bahasa Indonesia. Ini sering tidak disadari oleh guru. Karena bahasa siswa tidak sama dengan bahasa guru, maka siswa tidak bisa menerima pesan dari guru secara tepat.

Dalam proses pembelajaran sering dijumpai kegagalan yang disebabkan oleh lemahnya sistem komunikasi. Untuk itu, guru perlu mengembangkan pola komunikasi efektif dalam proses pembelajaran. Belum dipahaminya bahasa verbal yang digunakan guru dalam pembelajaran. Belum maksimalnya bahasa tubuh yang digunakan guru untuk mendukung bahasa verbalnya.

Berdasarkan fakta-fakta di atas, penulis berminat melakukan penelitian dengan judul: "Pengaruh Komunikasi dalam Pembelajaran terhadap Hasil Belajar Kognitif Pada Mata Pelajaran Sejarah Kebudayaan Islam di

\footnotetext{
${ }^{1}$ Ibid., hlm. 90.
}

Madrasah Ibtidaiyah Nurul Jihad Kecamatan Tembilahan Hulu".

Rumusan masalah sebagai berikut: Bagaimana pengaruh komunikasi dalam pembelajaran terhadap hasil belajar kognitif pada mata pelajaran Sejarah Kebudayaan Islam di Madrasah Ibtidaiyah Nurul Jihad Kecamatan Tembilahan Hulu?

\section{Pengertian Komunikasi}

Sebagai makhluk sosial, manusia perlu berkomunikasi dengan orang lain untuk menyelesaikan berbagai permasalahan. Dalam proses belajar mengajar, komunikasi merupakan faktor kunci yang turut menentukan keberhasilan suatu proses pembelajaran.

Dalam kamus bahasa Indonesia, komunikasi diartikan sebagai pengiriman dan penerimaan pesan atau berita antara dua orang atau lebih sehingga pesan yang dimaksud dapat dipahami. ${ }^{2}$ Sedangkan M. Sobry Sutikno menjelaskan komunikasi sebagai suatu proses penyampaian pesan atau informasi dari satu pihak kepada pihak lain agar terjadi saling mempengaruhi di antara keduanya. ${ }^{3}$ Di dalam modul organisasi dan manajemen, komunikasi dapat diartikan sebagai proses mentransfer informasi, makna, dan pengertian yang dilakukan dalam bentuk

${ }^{2}$ Departemen Pendidikan Nasional, Kamus Besar Bahasa Indonesia Pusat Bahasa, (Jakarta: Gramedia Pustaka Utama, 2008), hlm. 721.

${ }^{3}$ M. Sobry Sutikno, Belajar dan Pembelajaran; Upaya Kreatif dalam Mewujudkan Pembelajaran Yang Berhasil, (Bandung: Prospect, 2009), hlm. 63. 
menulis, membaca, berbicara, atau mendengarkan. ${ }^{4} \quad$ Berkomunikasi melibatkan beberapa unsur. dalam proses pembelajaran akan melibatkan, yaitu:

a. Komunikator (pembawa pesan).

b. Komunikan (penerima pesan).

c. Tujuan.

d. Ide atau Gagasan.

e. Tersedia saluran yang dapat menghubungkan sumber informasi dengan penerima informasi.

f. Respon dari penerima pesan.

g. Noise. $^{5}$

Unsur pertama dan paling utama adalah adanya seorang komunikator (pembawa pesan) yang mempunyai sejumlah kebutuhan berupa ide-ide, sasaran-sasaran, atau gagasan yang dapat membantu berbagai pemecahan masalah. Kedua adalah adanya penerima pesan, yaitu orang yang akan menerima pesan yang disampaikan oleh komunikator. Di samping itu didalam komunikasi juga ada tujuan yang ingin dicapai, dan gagasan atau ide yang perlu disampaikan.

Hubungan komunikasi hanya akan terjadi bila ada saluran yang dapat menghubungkannya. Selanjutnya sebagai hasil dari komunikasi akan ada respon dari penerima pesan. Dalam komunikasi ada noise, yaitu gangguan tidak terencana yang terjadi dalam proses komunikasi sebagai akibat diterimanya pesan lain oleh

\footnotetext{
${ }^{4}$ Deddy Yusuf Yudhyarta, Modul Organisasi dan Manajemen, (Tembilahan: STAI Auliaurrasyidin, 2011), hlm. 60.

${ }^{5}$ Yuhara Sukra, Pedoman Perbaikan Pendidikan, (Jakarta: UI Press, 2004), hlm. 86.
}

komunikan yang berbeda dengan pesan yang disampaikan oleh komunikator kepadanya.

\section{Komunikasi dalam Proses Pembelajaran \\ Komunikasi dalam proses} pembelajaran yang penulis maksudkan di sini adalah hubungan atau interaksi antara guru dengan siswa yang berlangsung pada saat proses pembelajaran, atau dengan istilah lain yaitu hubungan aktif antara guru dengan siswa dalam pelaksanaan proses pembelajaran.

Ada tiga pola komunikasi yang dapat digunakan untuk mengembangkan interaksi dinamis antara guru dengan siswa menurut Nana Sudjana, yaitu:

a. Komunikasi sebagai aksi atau komunikasi satu arah.

b. Komunikasi sebagai interaksi atau komunikasi dua arah.

c. Komunikasi banyak arah atau komunikasi sebagai transaksi. ${ }^{6}$

Dalam komunikasi sebagai aksi atau komunikasi satu arah, guru berperan sebagai pemberi aksi dan siswa sebagai penerima aksi. Guru aktif dan siswa pasif. Ceramah pada dasarnya adalah komunikasi satu arah, atau komunikasi sebagai aksi.

Dalam komunikasi sebagai interaksi atau komunikasi dua arah, guru dan siswa dapat berperan sama yaitu pemberi aksi dan penerima aksi. Di sini, sudah terlihat 2 (dua) arah, tetapi terbatas antara guru dan siswa secara individual. Antara siswa dan

${ }^{6}$ Nana Sudjana, Dasar-dasar Proses Belajar Mengajar, (Bandung: Sinar Baru Algesindo, 2000), hlm. 89. 
siswa tidak ada hubungan. Siswa tidak dapat berdiskusi dengan teman atau bertanya sesama temannya. Keduanya dapat saling memberi dan menerima. Komunikasi ini lebih baik dari pada yang pertama, sebab kegiatan guru dan kegiatan siswa relatif sama.

Sedangkan komunikasi banyak arah atau komunikasi sebagai transaksi yaitu komunikasi tidak hanya melibatkan interaksi dinamis antara guru dengan siswa tetapi juga melibatkan interaksi yang dinamis antara siswa yang satu dengan siswa yang lainnya. Proses pembelajaran dengan pola komunikasi ini mengarah kepada proses pembelajaran yang mengembangkan kegiatan siswa yang optimal, sehingga menumbuhkan siswa belajar aktif. Diskusi, simulasi merupakan strategi yang dapat mengembangkan komunikasi ini.

Dari ketiga pola komunikasi tersebut, untuk mewujudkan pembelajaran efektif dianjurkan agar guru membiasakan diri menggunakan komunikasi pola ketiga yaitu komunikasi sebagai transaksi atau komunikasi banyak arah. Komunikasi sebagai transaksi akan menempatkan guru pada posisi sebagai pemimpin belajar atau pembimbing belajar atau fasilitator belajar. Sebaliknya siswa di samping sebagai objek dapat pula berperan sebagai subjek.

Adapun upaya yang dapat dilakukan guru untuk membangun komunikasi yang efektif dalam proses pembelajaran adalah sebagai berikut:

a. Mengetahui tujuan. b. Mengetahui mitra bicara untuk menggunakan bahasa yang dapat dipahami.

c. Respek (menghargai).

d. Empati (menempatkan diri sebagai siswa).

e. Audibel

f. Raut muka yang sesuai.

g. Bahasa tubuh yang mendukung.

h. Bahasa verbal yang jelas.

i. Jelas maknanya.

j. Bijaksana dengan cara menginformasikan kembali. ${ }^{7}$

Tujuan kita berkomunikasi akan sangat menentukan cara kita menyampaikan informasi. Kejelasan tujuan dalam berkomunikasi harus diketahui sebelum kita berkomunikasi. ${ }^{8}$ Tujuan berkomunikasi tersebut sesuai dengan apa yang ingin disampaikan dalam proses pembelajaran.

Sedangkan empati adalah kemampuan untuk menempatkan diri kita pada situasi dan kondisi yang dihadapi orang lain. ${ }^{9}$ Syarat utama dari sikap empati adalah kemampuan untuk mendengar dan mengerti orang lain, sebelum didengar dan dimengerti keinginannya, tetapi ia akan berusaha memahami siswanya terlebih dahulu. Ia akan membuka dialog dengan mereka, mendengar keluhan dan harapannya.

${ }^{7}$ M. Sobry Sutikno, Model Pembelajaran Interaksi Sosial, Pembelajaran Efektif dan Retorika, (Mataram: NTP Press, 2004), hlm. 73.

${ }^{8}$ Ibid., hlm. 67.

${ }^{9}$ Abu Ahmadi, Psikologi Belajar, (Jakarta: Rineka Cipta, 2004), hlm. 67. 
Audibel berarti dapat didengarkan atau bisa dimengerti dengan baik. ${ }^{10}$ Sebuah pesan harus dapat disampaikan dengan cara atau sikap yang bisa diterima oleh si penerima pesan. Raut muka yang cerah, bahasa tubuh yang baik, kata-kata yang sopan, atau cara menunjuk, termasuk ke dalam komunikasi yang audibel.

Pesan yang disampaikan harus jelas maknanya dan tidak menimbulkan banyak pemahaman, selain harus terbuka dan transparan. Ketika berkomunikasi dengan siswa, guru harus berusaha agar pesan yang disampaikan bisa jelas maknanya.

Sikap bijaksana mengandung makna saling menghargai, tidak memandang rendah, dan penuh pengendalian diri. ${ }^{11}$

Dalam berkomunikasi terhadap siswanya, guru harus menyampaikan dengan lemah lembut, kata-kata sopan, dan menempatkan siswanya pada posisi yang dihargai atau tidak menganggap remeh.

Terdapat empat fungsi komunikasi dalam sebuah kelompok organisasi atau lembaga, yaitu: Kontrol, Motivasi, Ekspresi emosional dan Informasi $^{12}$

\section{Pengertian Pembelajaran}

Menurut Winkel dalam M. Sobry Sutikno pembelajaran diartikan sebagai: Ilmu siasat perang, siasat perang, bahasa pembicaraan akal (tipu

${ }^{10}$ Sarlito Wirawan, Pengantar Umum Psikologi, (Jakarta: Bulan Bintang, 2006), hlm. 76.

${ }^{11}$ Ibid., hlm. 83. 60.

${ }^{12}$ Deddy Yusuf Yudhyarta, Op. Cit., hlm. muslihat) untuk mencapai suatu maksud. Sedangkan Pembelajaran merupakan terjemahan dari kata "instruction" yang dalam bahasa Yunani disebut instructus atau "intruere" yang berarti menyampaikan pikiran, dengan demikian arti instruksional adalah menyampaikan pikiran atau ide yang telah diolah secara bermakna melalui pembelajaran. ${ }^{13}$

Secara implisit, di dalam pembelajaran, ada kegiatan memilih, menetapkan dan mengembangkan metode untuk mencapai hasil pembelajaran yang diinginkan. Pembelajaran lebih menekankan pada cara-cara untuk mencapai tujuan dan berkaitan dengan bagaimana cara mengorganisasikan materi pelajaran, menyampaikan materi pelajaran, dan mengelola pembelajaran.

Dalam proses pembelajaran, kedudukan guru sudah tidak dapat lagi dipandang sebagai penguasa tunggal dalam kelas atau sekolah, tetapi dianggap sebagai manager of learning (pengelola belajar) yang perlu senantiasa siap membimbing dan membantu para siswa dalam menempuh perjalanan menuju kedewasaan mereka sendiri yang utuh menyeluruh.

Oemar Hamalik memaparkan tiga ciri khas yang terkandung dalam pembelajaran, yaitu rencana, kesaling ketergantungan, dan tujuan. ${ }^{14}$ Rencana merupakan penataan ketenagaan,

\footnotetext{
${ }^{13}$ Ibid., hlm. 31.

${ }^{14}$ Oemar Hamalik, Kurikulum dan Pembelajaran, (Jakarta: Bumi Aksara, 2001),
} hlm. 24 
material, dan prosedur, yang merupakan unsur-unsur sistem pembelajaran, dalam suatu rencana khusus.

Tujuan merupakan sistem pembelajaran yang mempunyai tujuan tertentu yang hendak dicapai. Ciri ini menjadi dasar perbedaan antara sistem yang dibuat oleh manusia dan sistem yang alami. Sistem yang dibuat oleh manusia, seperti sistem transportasi, sistem komunikasi, sistem pemerintahan, semuanya memiliki tujuan. Sistem alami seperti ekologi, sistem kehidupan hewan, memiliki unsur-unsur yang saling ketergantungan satu sama lain, disusun sesuai dengan rencana tertentu, tetapi tidak mempunyai tujuan tertentu. Tujuan sistem menuntun proses merancang sistem.

Selain pendapat di atas, Ahmad Azhari mengemukakan ciri-ciri pembelajaran sebagai berikut:

a. Memiliki tujuan, yaitu untuk membentuk siswa dalam suatu perkembangan tertentu.

b. Terdapat mekanisme, prosedur, langkah-langkah, metode dan teknik yang direncanakan dan didesain untuk mencapai tujuan yang telah ditetapkan.

c. Fokus materi jelas, terarah dan terencana dengan baik.

d. Adanya aktivitas siswa merupakan syarat mutlak bagi berlangsungnya kegiatan pembelajaran.

e. Aktor guru yang cermat dan tepat.

f. Terdapat pola aturan yang ditaati guru dan siswa dalam proporsi masing-masing. g. Limit waktu untuk mencapai tujuan pembelajaran.

h. Evaluasi, baik evaluasi proses maupun evaluasi produk. ${ }^{15}$

Oleh karena itu, materi pelajaran menurut Nana Sudjana merupakan unsur inti yang ada di dalam kegiatan pembelajaran, karena memang materi pelajaran itulah yang diupayakan untuk dikuasai oleh siswa. ${ }^{16}$ Dalam kegiatan pembelajaran, guru dan siswa terlibat dalam sebuah interaksi dengan materi pelajaran sebagai mediumnya. Dalam interaksi itu siswalah yang lebih aktif, bukan guru. Keaktifan siswa tentu mencakup kegiatan fisik dan mental, individual dan kelompok. Oleh karena itu interaksi dikatakan maksimal bila terjadi antara guru dengan semua siswa, antara siswa dengan guru, antara siswa dengan siswa, siswa dengan materi pelajaran dan media pembelajaran, bahkan siswa dengan dirinya sendiri, namun tetap dalam kerangka mencapai tujuan yang telah ditetapkan bersama.

Sedangkan metode merupakan suatu cara yang dipergunakan untuk mencapai tujuan yang telah ditetapkan. Dalam kegiatan pembelajaran, metode diperlukan oleh guru dengan penggunaan yang bervariasi sesuai dengan tujuan yang ingin dicapai. ${ }^{17}$ Sedangkan media merupakan segala sesuatu yang dapat digunakan dalam

${ }^{15}$ Ahmad Azhari, Supervisi Rencana Program Pembelajaran, (Jakarta: Riau Putra, 2001), hlm. 1.

${ }^{16}$ Nana Sudjana, Dasar-dasar Proses Belajar Mengajar, (Bandung: Sinar Baru Algesindo, 2000), hlm. 33.

${ }^{17}$ Arief S. Sadiman, Media Pendidikan, (Jakarta: Rajawali Pers, 2001), hlm. 12. 
rangka mencapai tujuan pembelajaran. ${ }^{18}$

Sumber belajar adalah segala sesuatu yang dapat dipergunakan sebagai bahan materi pelajaran. Baik berupa buku, alam sekitar, ataupun yang lainnya. Menurut Nasution, sumber belajar dapat berasal dari masyarakat dan kebudayaannya, perkembangan ilmu pengetahuan teknologi serta kebutuhan siswa. ${ }^{19}$

Pemanfaatan sumber-sumber belajar tersebut tergantung pada kreativitas guru, waktu, biaya serta kebijakan-kebijakan lainnya. Sumber belajar tidak hanya terbatas pada bahan dan alat yang digunakan dalam proses pembelajaran, melainkan juga tenaga, biaya, dan fasilitas.

Evaluasi adalah suatu tindakan atau suatu proses untuk menentukan nilai dari suatu tindakan atau suatu proses untuk menentukan nilai dari sesuatu. $^{20}$ Evaluasi adalah kegiatan mengumpulkan data seluas-luasnya dan sedalam-dalamnya mengenai kapabilitas siswa guna mengetahui sebab akibat dan hasil belajar siswa guna mendorong atau mengembangkan kemampuan belajar.

Jadi, evaluasi merupakan aspek yang penting yang berguna untuk sejauhmana kemajuan belajar siswa, dan bagaimana tingkat keberhasilan sesuai dengan tujuan pembelajaran tersebut.

${ }^{18}$ Ibid., hlm. 17.

${ }^{19}$ Nasution, Berbagai Pendekatan dalam Proses Belajar dan Mengajar, (Jakarta: Bumi Aksara, 2000), hlm. 71.

${ }^{20}$ Ibid., hlm. 76.

\section{Pengertian Kognitif}

Menurut Muhibbin Syah, ranah kognitif, meliputi kemampuan menyatakan kembali konsep atau prinsip yang telah dipelajari dan kemampuan intelektual. Istilah cognitive berasal dari kata cognition yang padanannya knowing, berarti mengetahui. Dalam arti luas, cognition (kognisi) ialah perolehan, penataan, dan penggunaan pengetahuan. ${ }^{21}$ Menurut Thohirin, kognitif pada dasarnya merupakan peristiwa mental, bukan peristiwa behavioral (yang bersifat jasmaniah) meskipun hal-hal yang bersifat behavioral tampak lebih nyata dalam hampir setiap peristiwa belajar siswa. ${ }^{22}$

Pembelajaran dalam kawasan kognitif menurut Bloom terdiri atas enam tingkatan yaitu: Pengetahuan, Pemahaman, Penerapan, Analisis. Dan Sintesis.

\begin{tabular}{|c|c|c|c|}
\hline $\begin{array}{l}\mathbf{N} \\
\mathbf{0}\end{array}$ & $\begin{array}{l}\text { Kate } \\
\text { gori } \\
\text { Jenis } \\
\text { Peril } \\
\text { aku }\end{array}$ & $\begin{array}{l}\text { Kemampuan } \\
\text { Internal }\end{array}$ & $\begin{array}{l}\text { Kata-Kata } \\
\text { Kerja } \\
\text { Operasional }\end{array}$ \\
\hline 1 & $\begin{array}{l}\text { Penge } \\
\text { tahua } \\
\mathrm{n}- \\
\text { ingata } \\
\mathrm{n}\end{array}$ & $\begin{array}{l}\text { Mengetahui } \\
\text { Misalnya: } \\
\text { Istilah, fakta, } \\
\text { aturan, urutan, } \\
\text { metode }\end{array}$ & $\begin{array}{l}\text { Mendefinisika } \\
\mathrm{n}, \\
\text { menyebutkan, } \\
\text { menunjukkan, } \\
\text { memberi nama } \\
\text { pada, } \\
\text { menyusun } \\
\text { daftar, } \\
\text { menggarisbaw } \\
\text { ahi, } \\
\text { menjodohkan, } \\
\text { memilih, } \\
\text { memberikan } \\
\text { definisi, }\end{array}$ \\
\hline
\end{tabular}

${ }^{21}$ Muhibbin Syah, Psikologi Pendidikan dengan Pendekatan Baru, (Bandung: Rosdakarya, 2008), hlm. 66.

${ }^{22}$ Thohirin, Psikologi Pembelajaran Pendidikan Agama Islam, (Jakarta: Rajawali Pers, 2005), hlm. 71. 


\begin{tabular}{|c|c|c|c|}
\hline & & & menyatakan. \\
\hline 2 & $\begin{array}{l}\text { Pema } \\
\text { ha } \\
\text { man }\end{array}$ & $\begin{array}{l}\text { Menterjemahka } \\
\mathrm{n} \\
\text { Menafsirkan } \\
\text { Memperkirakan } \\
\text { Menentukan } \\
\text { Misalnya: } \\
\text { Metode, } \\
\text { prosedur } \\
\text { Memahami } \\
\text { Misalnya: } \\
\text { Konsep, kaidah, } \\
\text { prinsip, kaitan } \\
\text { antara fakta, isi } \\
\text { pokok } \\
\text { Mengartikan/ } \\
\text { menginterpretasi } \\
\text { kan } \\
\text { Misalnya: tabel, } \\
\text { grafik, bagan }\end{array}$ & $\begin{array}{l}\text { Menjelaska, } \\
\text { menguraika, } \\
\text { merumuska, } \\
\text { merangkum, } \\
\text { mengubah, } \\
\text { memberikan } \\
\text { contoh } \\
\text { tentang, } \\
\text { menyadur, } \\
\text { meramalkan, } \\
\text { menyimpulka, } \\
\text { memperkiraka } \\
\text { n, } \\
\text { menerangkan. } \\
\text { Menggantikan } \\
\text { menarik } \\
\text { kesimpulan, } \\
\text { meringkas, } \\
\text { mengembangk } \\
\text { an, } \\
\text { membuktikan. }\end{array}$ \\
\hline 3 & $\begin{array}{l}\text { Pener } \\
\text { apan }\end{array}$ & $\begin{array}{l}\text { Memecahkan } \\
\text { masalah } \\
\text { Membuat bagan } \\
\text { dan grafik } \\
\text { Menggunakan } \\
\text { Misalnya: } \\
\text { metode/ } \\
\text { prosedur, } \\
\text { konsep, kaidah, } \\
\text { prinsip } \\
\text { Mengenali } \\
\text { kesalahan } \\
\text { Membedakan } \\
\text { Misalnya: fakta } \\
\text { dari interpretasi } \\
\text { data dari } \\
\text { kesimpulan } \\
\text { Menganalisa } \\
\text { Misalnya: } \\
\text { struktur dasar } \\
\text { bagian-bagian } \\
\text { hubungan antara }\end{array}$ & $\begin{array}{l}\text { Mendemonstra } \\
\text { sikan, } \\
\text { Menghitung, } \\
\text { menghubungk } \\
\text { an, } \\
\text { memperhitung } \\
\text { ka, } \\
\text { membuktikan, } \\
\text { menghasilkan, } \\
\text { menunjukkan, } \\
\text { melengkapi, } \\
\text { menyediakan, } \\
\text { menyesuaikan, } \\
\text { menemukan. } \\
\text { Memisahkan, } \\
\text { menerima, } \\
\text { menyisihkan, } \\
\text { menghubungk } \\
\text { an, memilih, } \\
\text { membandingk } \\
\text { an, } \\
\text { mempertentan } \\
\text { gkan } \\
\text { membagi, } \\
\text { membuat } \\
\text { diagram/skem } \\
\text { a, } \\
\text { menunjukkan } \\
\text { hubungan } \\
\text { antara, } \\
\text { membagi. }\end{array}$ \\
\hline 4 & $\begin{array}{l}\text { Anali } \\
\text { sis }\end{array}$ & $\begin{array}{l}\text { Mengenali } \\
\text { kesalahan } \\
\text { Membedakan } \\
\text { Misalnya: fakta } \\
\text { dari interpretasi }\end{array}$ & $\begin{array}{l}\text { Memisahka, } \\
\text { menerima, } \\
\text { menyisihka, } \\
\text { menghubungk } \\
\text { an, memilih, }\end{array}$ \\
\hline
\end{tabular}

\begin{tabular}{|c|c|c|c|}
\hline & & $\begin{array}{l}\text { data dari } \\
\text { kesimpulan } \\
\text { Menganalisa } \\
\text { Misalnya: } \\
\text { struktur dasar } \\
\text { bagian-bagian } \\
\text { hubungan antara }\end{array}$ & $\begin{array}{l}\text { membandingk } \\
\text { an, } \\
\text { mempertentan } \\
\text { gkan } \\
\text { membagi, } \\
\text { membuat } \\
\text { diagram/skem } \\
\text { a, } \\
\text { menunjukkan } \\
\text { hubungan } \\
\text { antara, } \\
\text { membagi }\end{array}$ \\
\hline 5 & $\begin{array}{l}\text { Sintes } \\
\mathrm{a}\end{array}$ & $\begin{array}{l}\text { Menghasilkan } \\
\text { Misalnya: } \\
\text { klasifikasi, } \\
\text { karangan, } \\
\text { kerangka teoritis } \\
\text { Menyusun } \\
\text { Misalnya: } \\
\text { rencana, skema, } \\
\text { program kerja }\end{array}$ & $\begin{array}{l}\text { Mengkategori } \\
\text { kan, } \\
\text { mengkombina } \\
\text { sikanmengara } \\
\text { ng, } \\
\text { menciptakan, } \\
\text { mendesain, } \\
\text { mengatur, } \\
\text { menyusun } \\
\text { kembali, } \\
\text { merangkaikan, } \\
\text { menhubungka } \\
\text { n, } \\
\text { menyimpulka, } \\
\text { merancangkan } \\
\text {, membuat } \\
\text { pola. }\end{array}$ \\
\hline 6 & $\begin{array}{l}\text { Evalu } \\
\text { asi }\end{array}$ & $\begin{array}{l}\text { Menilai } \\
\text { berdasarkan } \\
\text { norma internal } \\
\text { Misalnya: hasil } \\
\text { karya seni, mutu } \\
\text { karangan, mutu } \\
\text { pekerjaan, mutu } \\
\text { ceramah, } \\
\text { program } \\
\text { penataran } \\
\text { Menilai } \\
\text { berdasarkan } \\
\text { norma eksternal } \\
\text { Misalnya: hasil } \\
\text { karya seni, mutu } \\
\text { karangan, mutu } \\
\text { pekerjaan, mutu } \\
\text { ceramah, } \\
\text { program } \\
\text { penataran } \\
\text { Mempertimbang } \\
\text { kan } \\
\text { Misalnya: baik- } \\
\text { buruknya, pro- } \\
\text { kontranya, } \\
\text { untung-ruginya }\end{array}$ & $\begin{array}{l}\text { Memperbandi } \\
\text { ngkanmenyim } \\
\text { pulkan, } \\
\text { mengkritik, } \\
\text { mengevaluir, } \\
\text { membuktikan, } \\
\text { memberikan } \\
\text { argumentasi, } \\
\text { menafsirkan, } \\
\text { membahas, } \\
\text { menaksir, } \\
\text { memilih } \\
\text { antara, } \\
\text { menguraika, } \\
\text { membedakan, } \\
\text { melukiskan, } \\
\text { mendukung, } \\
\text { menyokong, } \\
\text { menolak. }\end{array}$ \\
\hline
\end{tabular}

Sumber: WS. Winkel, Psikologi Pengajaran, hlm. 155. 
Keenam jenis taksonomi tersebut diuraikan satu per satu berikut ini: Pengetahuan adalah kemampuan yang paling rendah tetapi paling dasar dalam kawasan kognitif. Kemampuan untuk mengetahui adalah kemampuan untuk mengenal atau mengingat kembali sesuatu objek, ide, prosedur, prinsip atau teori yang pernah ditemukan dalam pengalaman tanpa memanipulasikan nya dalam bentuk atau simbol lain. Kemampuan mengetahui sedikit lebih rendah dibawah kemampuan memahami, karena itu orang yang mengetahui belum tentu memahami atau mengerti apa yang diketahuinya.

Pemahaman adalah kemampuan untuk memahami segala pengetahuan yang diajarkan seperti kemampuan mengungkapkan dengan struktur kalimat lain, membandingkan, menafsirkan, dan sebagainya. Kemampuan memahami dapat juga disebut dengan istilah mengerti. Kemampuan-kemampuan yang tergolong dalam taksonomi ini, mulai dari yang terendah sampai yang tertinggi ialah:

1. Translasi, yaitu kemampuan untuk mengubah simbol tertentu menjadi simbol lain tanpa perubahan makna.

2. Interpretasi, yaitu kemampuan untuk menjelaskan makna yang terdapat di dalam simbol, baik simbol verbal maupun nonverbal.

3. Ekstrapolasi, yaitu kemampuan untuk melihat kecenderungan atau arah atau kelanjutan dari suatu temuan.
Menurut

Dariyanto, kemampuan kognitif meliputi unsurunsur berikut:

1. Tingkat pengetahuan (Knowledge). Pada tahap ini menuntut siswa untuk mampu mengingat (recall) berbagai informasi yang telah diterima sebelumnya, misalnya fakta, rumus, terminologi strategi problem solving dan lain sebagainya.

2. Tingkat pemahaman (Comprehension). Pada tahap ini kategori pemahaman dihubungkan dengan kemampuan untuk menjelaskan pengetahuan, informasi yang telah diketahui dengan kata-kata sendiri. Pada tahap ini peserta didik diharapkan menerjemahkan atau menyebutkan kembali yang telah didengar dengan kata-kata sendiri.

3. Tingkat penerapan (Application). Penerapan merupakan kemampuan untuk menggunakan atau menerapkan informasi yang telah dipelajari ke dalam situasi yang baru, serta memecahkan berbagai masalah yang timbul dalam kehidupan sehari-hari.

4. Tingkat analisis (Analysis). Analisis merupakan kemampuan mengidentifikasi, memisahkan dan membedakan komponenkomponen atau elemen suatu fakta, konsep, pendapat, asumsi, hipotesa atau kesimpulan, dan memeriksa setiap komponen tersebut untuk melihat ada atau tidaknya kontradiksi. Dalam tingkat ini peserta didik diharapkan menunjukkan hubungan di antara 
berbagai gagasan dengan cara membandingkan gagasan tersebut dengan standar, prinsip atau prosedur yang telah dipelajari.

5. Tingkat sintesis (Synthesis). Sintesis merupakan kemampuan seseorang dalam mengaitkan dan menyatukan berbagai elemen dan unsure pengetahuan yang ada sehingga terbentuk pola baru yang lebih menyeluruh.

6. Tingkat evaluasi (Evaluation). Evaluasi merupakan level tertinggi yang mengharapkan peserta didik mampu membuat penilaian dan keputusan tentang nilai suatu gagasan, metode, produk, atau benda dengan menggunakan kriteria tertentu. $^{23}$

Secara lebih konkret, Yusri Arryza menjelaskan pada tingkat pengetahuan, peserta didik menjawab pertanyaan berdasarkan hapalan saja. Pada tingkat pemahaman peserta didik dituntut untuk menyatakan masalah dengan kata-katanya sendiri, memberi contoh suatu konsep atau prinsip. Pada tingkat aplikasi, peserta didik dituntut untuk menerapkan prinsip dan konsep dalam situasi yang baru. Pada tingkat analisis, peserta didik diminta untuk menguraikan informasi ke dalam beberapa bagian, menemukan asumsi, membedakan fakta dan pendapat serta menemukan hubungan sebab-akibat. Pada tingkat sintesis, peserta didik dituntut untuk menghasilkan suatu cerita, komposisi, hipotesis atau teorinya sendiri dan mensintesiskan pengetahuannya. Pada tingkat

${ }^{23}$ Dariyanto, Evaluasi Pendidikan, (Jakarta: Bumi Aksara, 1995), hlm. 18. evaluasi, peserta didik mengevaluasi informasi seperti bukti, sejarah, editorial, teori-teori yang termasuk di dalamnya judgement terhadap hasil analisi untuk membuat kebijakan. ${ }^{24}$

Dengan demikian dapat disimpulkan bahwa kemampuan ranah kognitif dapat diukur dari:

1. Pengetahuan-ingatan

a. Mendefinisikan berbagai istilah dalam memahami materi Sejarah Kebudayaan Islam.

b. Menunjukkan contoh sesuai materi Sejarah Kebudayaan Islam.

c. Menuliskan secara berurutan materi pada pembelajaran Sejarah Kebudayaan Islam.

2. Pemahaman

a. Menjelaskan materi pada pembelajaran Sejarah Kebudayaan Islam.

b. Menulis kembali penjelasan materi Sejarah Kebudayaan Islam yang telah disampaikan.
c. Meringkas materi pembelajaran Sejarah Kebudayaan Islam.

3. Aplikasi

a. Mendemonstrasikan materi pembelajaran Sejarah Kebudayaan Islam.

b. Menghubungkan materi Sejarah Kebudayaan Islam dengan kehidupan nyata.

4. Analisis

${ }^{24}$ Yusri Arryza, Kemampuan Aspek Kognitif, Afektif dan Psikomotor, (Bandung: Remaja Rosdakarya, 2002),hlm. 28. 

a. Merincikan
materi pembelajaran
Sejarah
Kebudayaan Islam.
b. Menguraikan
kembali penjelasan guru pada materi Sejarah Kebudayaan Islam.

5. Sintesis
a. Menyimpulkan
materi pembelajaran
Sejarah
Kebudayaan Islam.
b. Menulis kembali penjelasan pada materi Sejarah Kebudayaan Islam.

6. Evaluasi

a. Meringkas kembali penjelasan guru tentang materi Sejarah Kebudayaan Islam.

\section{Tujuan Pembelajaran Kognitif}

Tujuan pembelajaran kognitif, berorientasi kepada kemampuan berfikir, mencakup kemampuan intelektual yang lebih sederhana, yaitu mengingat, sampai pada kemampuan memecahkan masalah yang menuntutkan siswa untuk menghubungkan dan menggabungkan gagasan, metode atau prosedur yang sebelumnya dipelajari untuk memecahkan masalah tersebut. Sehingga dapat disimpulkan bahwa kawasan kognitif adalah sub taksonomi yang mengungkapkan tentang kegiatan mental yang sering berawal dari tingkat pengetahuan sampai ke tingkat yang paling tinggi, yaitu evaluasi. ${ }^{25}$

Kawasan kognitif terdiri dari enam tingkatan dengan aspek belajar

${ }^{25}$ Martinis Yamin, Strategi Pembelajaran Berbasis Kompetensi, (Jakarta: Gung Persada Press, 2012), hlm. 27. yang berbeda-beda. Keenam tingkat tersebut adalah:

1. Tingkat Pengetahuan (Knowledge)

Tujuan instruksional pada

level ini menuntut siswa untuk mampu mengingat (recall) informasi yang telah diterima sebelumnya, seperti, misalnya: fakta, terminologi, rumus, strategi pemecahan masalah, dan sebagainya. Contoh:

a. Siswa dapat menyebutkan kembali nama-nama menteri dalam kabinet gotong royong.

b. Siswa dapat menggambarkan struktur kelembagaan negara Indonesia.

c. Siswa dapat mengurutkan nama-nama presiden Indonesia dari pertama sampai sekarang.

2. Tingkat Pemahaman (Comprehension)

Kategori pemahaman dihubungkan dengan kemampuan untuk menjelaskan pengetahuan, informasi yang telah diketahui dengan kata-kata sendiri. Dalam hal ini siswa diharapkan menerjemahkan atau menyebutkan kembali yang telah di dengar dengan kata-kata sendiri. Contoh:
a. Siswa dapat menjelaskan tentang cara menanggulangi bahaya banjir.
b. Siswa dapat mengkaji ulang akibat penggundulan hutan.
c. Siswa dapat menggambarkan tentang akibat banjir yang telah mereka lihat.

3. Tingkat Penerapan (Aplication)

$$
\text { Penerapan merupakan }
$$

kemampuan untuk menggunakan 
atau menerapkan informasi yang telah dipelajari ke dalam situasi yang baru, serta memecahkan berbagai masalah yang timbul dalam kehidupan sehari-hari.

4. Tingkat Analisis (Analysis)

Analisis merupakan kemampuan untuk mengidentifikasi, memisahkan dan membedakan komponenkomponen atau elemen suatu fakta, konsep, pendapat asumsi, hipotesa atau kesimpulan, dan memeriksa setiap komponen tersebut untuk melihat ada tidaknya kontradiksi. Dalam hal ini siswa diharapkan menunjukkan hubungan di antara berbagai gagasan dengan cara membandingkan gagasan tersebut dengan standar, prinsip atau prosedur yang telah dipelajari. Contoh:

a. Siswa dapat menginventarisir kewajiban sebagai warga negara Indonesia.

b. Siswa dapat menganalisis sejauh mana hasil diskusi mereka tentang kewajiban dan hak sebagai warga negara Indonesia.

5. Tingkat Sintesis (Synthesis)

Sintesis di sini diartikan sebagai kemampuan seseorang dalam mengaitkan dan menyatukan berbagai elemen dan unsur pengetahuan yang ada sehingga terbentuk pola baru yang lebih menyeluruh. Contoh:

a. Siswa dapat mengumpulkan dana untuk bantuan terhadap rekannya yang tertimpa musibah. b. Siswa dapat menyiapkan bahan pelajaran yang akan didiskusikan.

c. Siswa dapat merancangkan kegiatan-kegiatan bakti sosial mereka di tengah-tengah masyarakat.

6. Tingkat Evaluasi (Evaluation)

Evaluasi merupakan level tertinggi, yang mengharapkan siswa mampu membuat penilaian dan keputusan tentang nilai suatu gagasan, metode, produk atau benda dengan menggunakan kriteria tertentu. Jadi, evaluasi di sini lebih condong ke bentuk penilaian biasa dari pada sistem evaluasi. Contoh:

a. Siswa dapat memilih kegiatan sesuai dengan bakatnya dari kegiatan pilihan yang telah ditetapkan sekolah.

b. Siswa dapat mengoreksi latihan conversationnya melalui rekaman tape.

c. Siswa dapat menilai unsur: kepadatan isi, cakupan materi, kualitas, analisis, dan gaya bahasa yang dipakai oleh seseorang penulis makalah tertentu. $^{26}$

\section{B. METODOLOGI}

Penelitian ini dilaksanakan di Madrasah Ibtidaiyah Nurul Jihad Kecamatan Tembilahan Hulu Subjek dalam penelitian ini adalah guru Sejarah Kebudayaan Islam di Madrasah Ibtidaiyah Nurul Jihad Kecamatan Tembilahan Hulu.

\footnotetext{
${ }^{26}$ Ibid., hlm. 28-30.
} 
Sedangkan objek dalam penelitian ini adalah pengaruh komunikasi dalam pembelajaran terhadap hasil belajar kognitif pada mata pelajaran Sejarah Kebudayaan Islam di Madrasah Ibtidaiyah Nurul Jihad Kecamatan Tembilahan Hulu. populasi dalam penelitian ini adalah guru Sejarah Kebudayaan Islam dan seluruh siswa kelas tinggi di Madrasah Ibtidaiyah Nurul Jihad Kecamatan Tembilahan Hulu, yang berjumlah 1 orang guru dan 130 orang siswa kelas tinggi, yaitu kelas IV, V, dan VI.

Sampel dalam penelitian ini di ambil sebanyak $20 \%$, dari siswa kelas IV, V, dan VI, yaitu $130 \times 20 \%=26$ orang siswa. Jenis sampel yang penulis gunakan adalah Random Sampling, yaitu teknik sampel dengan cara acak.

Data dalam penelitian ini dikumpulkan dengan menggunakan teknik sebagai berikut: observasi dan dokumentasi Data yang sudah terkumpul, penulis kualifikasikan atau tuangkan ke dalam bentuk angkaangka. Sehingga data tersebut bersifat kuantitatif. Untuk selanjutnya dianalisa dan diinterpretasikan secara deskriptif.

Pengalihan data ke dalam bentuk kuantitatif ini ditempuh dengan menggunakan rumus porsentase

Adapun langkah menentukan berpengaruh atau tidaknya komunikasi dalam pembelajaran terhadap hasil belajar kognitif di cari dengan rumus uji t:

$$
t=\frac{\bar{X}-\bar{Y}}{\sqrt{S_{x-y}^{2}\left(\frac{1}{n x}-\frac{1}{n y}\right)}}
$$

Keterangan:

$\mathrm{t}=$ nilai deviasi pada distribusi

$\overline{\mathrm{X}} \quad \mathrm{t}=$ nilai rata-rata variabel $\mathrm{X}$

$\overline{\mathrm{Y}} \quad=$ nilai rata-rata variabel $\mathrm{Y}$

$\mathrm{S}^{2} \mathrm{x}-\mathrm{y} \quad=$ standar deviasi

$\mathrm{nx} \quad=$ jumlah sampel $\mathrm{X}$

ny $\quad=$ jumlah sampel $\mathrm{Y}^{27}$

Terlebih dahulu mencari nilai rata-rata variabel $\mathrm{X}$, yaitu:

Nilai $\bar{X}=\frac{\sum X}{N x}$

Selanjutnya mencari nilai rata-rata variabel Y, yaitu:

Nilai $\bar{Y}=\frac{\sum Y}{\text { ny }}$

Selanjutnya mencari varians $\left(S^{2} x-y\right)$ dengan rumus sebagai berikut:

$$
\mathrm{S}_{\mathrm{xy}}^{2}=\frac{\sum(\mathrm{X}-\mathrm{X})^{2}+\sum(\mathrm{Y}-\mathrm{Y})^{2}}{\mathrm{n}_{\mathrm{x}}+\mathrm{n}_{\mathrm{y}}-2}
$$

Kriterianya adalah Jika thitung $\leq$ ttabel, maka Ho ditolak, dan Ha di terima.

\section{PEMBAHASAN}

Penyajian Data Variabel X. Variabel $\mathrm{X}$ dalam penelitian ini adalah komunikasi dalam pembelajaran pada mata pelajaran Sejarah Kebudayaan Islam di Madrasah Ibtidaiyah Nurul Jihad Kecamatan Tembilahan Hulu. Data untuk variabel $\mathrm{X}$ dikumpulkan dengan menggunakan teknik observasi. Observasi dilakukan kepada bapak Hanapis, S.Pd.I, selaku guru mata pelajaran Sejarah Kebudayaan Islam kelas IV, V, dam VI. Bapak Hanapis

${ }^{27}$ Riduwan, Dasar-Dasar Statistika, (Bandung: Alfabeta, 2010), hlm. 214. 
diobservasi sebanyak 6 (enam) kali, dengan ketentuan sebagai berikut:

Alternatif jawaban sangat baik diberi skor 4

Alternatif jawaban baik diberi skor 3

Alternatif jawaban cukup baik diberi skor $2^{28}$

Data hasil observasi disajikan dalam tabel-tabel berikut ini. Selanjutnya hasil observasi tentang komunikasi dalam pembelajaran pada mata pelajaran Sejarah Kebudayaan Islam di Madrasah Ibtidaiyah Nurul Jihad Kecamatan Tembilahan Hulu tersebut direkapitulasi sebagaimana tabel di bawah ini.

Rekapitulasi Hasil Observasi Komunikasi dalam Pembelajaran Pada Mata Pelajaran Sejarah Kebudayaan Islam di Madrasah Ibtidaiyah Nurul Jihad Kecamatan Tembilahan Hulu (Variabel X)

\begin{tabular}{|c|c|c|c|c|c|c|c|}
\hline \multirow{3}{*}{$\begin{array}{l}\mathbf{N} \\
\mathbf{0}\end{array}$} & \multirow{3}{*}{ Tabel } & \multicolumn{6}{|c|}{ Hasil Observasi } \\
\hline & & \multicolumn{2}{|c|}{$\begin{array}{c}\text { Sangat } \\
\text { Baik }\end{array}$} & \multicolumn{2}{|c|}{ Baik } & \multicolumn{2}{|c|}{$\begin{array}{c}\text { Cukup } \\
\text { Baik }\end{array}$} \\
\hline & & $F$ & $\mathrm{P}$ & $\mathrm{F}$ & $P$ & $\mathrm{~F}$ & $\mathrm{P}$ \\
\hline 1 & IV.4 & 0 & 0 & 12 & 54,55 & 10 & 45,45 \\
\hline 2 & IV.5 & 0 & 0 & 15 & 65,22 & 8 & 34,78 \\
\hline 3 & IV.6 & 0 & 0 & 15 & 65,22 & 8 & 34,78 \\
\hline 4 & IV.7 & 12 & 40 & 18 & 60 & 0 & 0 \\
\hline 5 & IV.8 & 12 & 41,38 & 15 & 51,72 & 2 & 6,90 \\
\hline 6 & IV.9 & 16 & 53,33 & 12 & 40 & 2 & 6,67 \\
\hline \multicolumn{2}{|c|}{ Jumlah } & 40 & 25,48 & 87 & 55,41 & 30 & 19,11 \\
\hline
\end{tabular}

Peryataan:

1. Guru menyampaikan tujuan pembelajaran

2. Guru menyampaikan informasi dengan bahasa yang dapat dipahami

3. Guru menghargai tanggapan siswa dengan pujian.

4. Guru duduk bersama siswa dalam membimbing.

5. Guru berbicara dengan raut muka yang sesuai dengan intonasi suaranya.

6. Guru berbicara dengan gaya tubuh yang sesuai dengan materi pelajaran.

${ }^{28}$ Sukardi, Metodologi Penelitian Pendidikan, (Jakarta: Bumi Aksara, 2003), hlm. 147.
7. Guru berbicara dengan bahasa verbal yang menarik.

8. Guru menyampaikan makna informasi secara jelas.

9. Guru menyampaikan kembali informasi informasi yang belum dipahami siswa, walaupun sebagian siswa telah mengetahui informasi tersebut.

Dari tabel di atas diketahui bahwa dari keseluruhan hasil observasi variabel $\mathrm{X}$ adalah alternatif Jawaban Sangat Baik 40 (25,48\%), alternatif jawaban baik $87(55,41 \%)$, alternatif jawaban cukup baik 30 (19,11\%), dengan jumlah total 157 (100\%).

Sehingga $F=157$, dan

$\mathrm{N}=$ Jumlah Populasi $\mathrm{x}$ Jumlah Aspek Yang Diobservasi $\mathrm{x}$ Jumlah Observasi $\mathrm{x}$ skor tertinggi

$=1 \times 9 \times 6 \times 4$

$=216$

Untuk mengetahui komunikasi dalam pembelajaran pada mata pelajaran Sejarah Kebudayaan Islam di Madrasah Ibtidaiyah Nurul Jihad Kecamatan Tembilahan Hulu, digunakan rumus:

$$
\begin{aligned}
P & =\frac{F}{N} \times 100 \% \\
P & =\frac{157}{216} \\
& =72,69 \%
\end{aligned}
$$

Dengan demikian dapat disimpulkan bahwa komunikasi dalam pembelajaran pada mata pelajaran Sejarah Kebudayaan Islam di Madrasah Ibtidaiyah Nurul Jihad Kecamatan Tembilahan Hulu, mencapai angka $72,69 \%$ dan dikategorikan baik, karena angka 
$72,69 \%$ terletak pada interval $61 \%$ $80 \%$.

Data variabel Y dalam penelitian ini adalah hasil belajar kognitif siswa pada mata pelajaran Sejarah Kebudayaan Islam di Madrasah Ibtidaiyah Nurul Jihad Kecamatan Tembilahan Hulu. Data untuk variabel $\mathrm{Y}$ dikumpulkan dengan menggunakan teknik observasi kepada 26 orang siswa kelas IV, V, dan VI. Masing-masing siswa diobservasi sebanyak 3 (tiga) kali, dengan ketentuan sebagai berikut:

\section{Rekapitulasi Hasil Observasi Hasil Belajar Kognitif Siswa Pada Mata Pelajaran Sejarah Kebudayaan Islam di Madrasah Ibtidaiyah Nurul Jihad Kecamatan Tembilahan Hulu (Variabel Y)}

\begin{tabular}{|c|c|c|c|c|c|c|c|c|c|}
\hline \multirow{3}{*}{$\begin{array}{l}\mathbf{N} \\
\mathbf{0}\end{array}$} & \multirow{3}{*}{$\begin{array}{c}\text { Tab } \\
\text { el }\end{array}$} & \multicolumn{8}{|c|}{ Hasil Observasi } \\
\hline & & \multicolumn{2}{|c|}{$\begin{array}{c}\text { Sangat } \\
\text { Baik }\end{array}$} & \multicolumn{2}{|c|}{ Baik } & \multicolumn{2}{|c|}{$\begin{array}{c}\text { Cukup } \\
\text { Baik }\end{array}$} & \multicolumn{2}{|c|}{$\begin{array}{l}\text { Tidak } \\
\text { Baik }\end{array}$} \\
\hline & & $\mathbf{F}$ & $\mathbf{P}$ & $\mathbf{F}$ & $\mathbf{P}$ & $\mathbf{F}$ & $\mathbf{P}$ & $\mathbf{F}$ & $\mathbf{P}$ \\
\hline 1 & $\begin{array}{l}\text { IV.1 } \\
1\end{array}$ & 0 & 0 & 30 & 37,97 & 40 & $\begin{array}{c}50,6 \\
3\end{array}$ & 9 & $\begin{array}{l}11, \\
39\end{array}$ \\
\hline 2 & $\begin{array}{l}\text { IV.1 } \\
2\end{array}$ & 0 & 0 & 18 & 23,68 & 50 & $\begin{array}{c}65,7 \\
9\end{array}$ & 8 & $\begin{array}{l}10, \\
53\end{array}$ \\
\hline 3 & $\begin{array}{l}\text { IV.1 } \\
3\end{array}$ & 0 & 0 & 27 & 33,33 & 48 & $\begin{array}{c}59,2 \\
6\end{array}$ & 6 & $\begin{array}{c}7,4 \\
1\end{array}$ \\
\hline 4 & $\begin{array}{l}\text { IV.1 } \\
4\end{array}$ & 0 & 0 & 42 & 49,41 & 36 & $\begin{array}{c}42,3 \\
5\end{array}$ & 7 & $\begin{array}{c}8,2 \\
4\end{array}$ \\
\hline 5 & $\begin{array}{l}\text { IV.1 } \\
5\end{array}$ & 16 & 16 & 54 & 54 & 26 & 26 & 4 & 4 \\
\hline 6 & $\begin{array}{l}\text { IV.1 } \\
6\end{array}$ & 0 & 0 & 15 & 20 & 52 & \begin{tabular}{|c|}
69,3 \\
3
\end{tabular} & 8 & $\begin{array}{l}10, \\
67\end{array}$ \\
\hline 7 & $\begin{array}{l}\text { IV.1 } \\
7\end{array}$ & 0 & 0 & 18 & 23,68 & 50 & $\begin{array}{c}65,7 \\
9\end{array}$ & 8 & $\begin{array}{l}10, \\
53\end{array}$ \\
\hline 8 & $\begin{array}{l}\text { IV.1 } \\
8\end{array}$ & 0 & 0 & 18 & 24,66 & 44 & $\begin{array}{c}60,2 \\
7\end{array}$ & 11 & $\begin{array}{l}15, \\
07\end{array}$ \\
\hline 9 & $\begin{array}{l}\text { IV.1 } \\
9\end{array}$ & 0 & 0 & 15 & 20 & 52 & $\begin{array}{c}69,3 \\
3\end{array}$ & 8 & $\begin{array}{l}10, \\
67\end{array}$ \\
\hline 10 & $\begin{array}{l}\text { IV.2 } \\
0\end{array}$ & 0 & 0 & 9 & 13,04 & 48 & $\begin{array}{c}69,5 \\
7\end{array}$ & 12 & $\begin{array}{l}17, \\
39 \\
\end{array}$ \\
\hline 11 & $\begin{array}{l}\text { IV.2 } \\
1\end{array}$ & 0 & 0 & 18 & 23,68 & 50 & $\begin{array}{c}65,7 \\
9\end{array}$ & 8 & $\begin{array}{l}10, \\
53\end{array}$ \\
\hline 12 & $\begin{array}{l}\text { IV.2 } \\
2\end{array}$ & 0 & 0 & 33 & 40,24 & 42 & $\begin{array}{c}51,2 \\
2\end{array}$ & 7 & $\begin{array}{c}8,5 \\
4\end{array}$ \\
\hline 13 & $\begin{array}{l}\text { IV.2 } \\
3\end{array}$ & 0 & 0 & 36 & 41,38 & 48 & $\begin{array}{c}55,1 \\
7\end{array}$ & 3 & $\begin{array}{c}3,4 \\
5\end{array}$ \\
\hline
\end{tabular}

\begin{tabular}{|c|c|c|c|c|c|c|c|c|c|}
\hline 14 & $\begin{array}{l}\text { IV.2 } \\
4\end{array}$ & 0 & 0 & 30 & 37,97 & 40 & \begin{tabular}{|c}
50,6 \\
3
\end{tabular} & 9 & \begin{tabular}{|l|}
11, \\
39
\end{tabular} \\
\hline 15 & $\begin{array}{l}\text { IV. } 2 \\
5\end{array}$ & 0 & 0 & 42 & 49,41 & 36 & $\begin{array}{c}42,3 \\
5\end{array}$ & 7 & $\begin{array}{c}8,2 \\
4\end{array}$ \\
\hline 16 & $\begin{array}{l}\text { IV.2 } \\
6\end{array}$ & 4 & 4,82 & 39 & 46,99 & 30 & $\begin{array}{c}36,1 \\
4\end{array}$ & 10 & $\begin{array}{l}12, \\
05\end{array}$ \\
\hline 17 & $\begin{array}{l}\text { IV. } 2 \\
7\end{array}$ & 0 & 0 & 30 & 37,97 & 40 & $\begin{array}{c}50,6 \\
3\end{array}$ & 9 & $\begin{array}{l}11, \\
39\end{array}$ \\
\hline 18 & $\begin{array}{l}\text { IV.2 } \\
8\end{array}$ & 0 & 0 & 3 & 4,76 & 44 & $\begin{array}{c}69,8 \\
4\end{array}$ & 16 & $\begin{array}{l}25 \\
40\end{array}$ \\
\hline 19 & $\begin{array}{l}\text { IV.2 } \\
9\end{array}$ & 0 & 0 & 9 & 13,43 & 44 & $\begin{array}{c}65,6 \\
7\end{array}$ & 14 & $\begin{array}{c}20 \\
90\end{array}$ \\
\hline 20 & $\begin{array}{l}\text { IV.3 } \\
0\end{array}$ & 0 & 0 & 27 & 33,33 & 48 & $\begin{array}{c}59,2 \\
6\end{array}$ & 6 & $\begin{array}{c}7,4 \\
1\end{array}$ \\
\hline 21 & $\begin{array}{l}\text { IV.3 } \\
1\end{array}$ & 0 & 0 & 3 & 4,92 & 40 & $\begin{array}{c}65,5 \\
7\end{array}$ & 18 & $\begin{array}{c}29 \\
51\end{array}$ \\
\hline 22 & $\begin{array}{l}\text { IV.3 } \\
2\end{array}$ & 0 & 0 & 18 & 25 & 42 & $\begin{array}{c}58,3 \\
3\end{array}$ & 12 & $\begin{array}{l}16 \\
67\end{array}$ \\
\hline 23 & $\begin{array}{l}\text { IV.3 } \\
3\end{array}$ & 0 & 0 & 27 & 33,33 & 48 & $\begin{array}{c}59,2 \\
6\end{array}$ & 6 & $\begin{array}{c}7,4 \\
1 \\
\end{array}$ \\
\hline 24 & $\begin{array}{l}\text { IV.3 } \\
4\end{array}$ & 0 & 0 & 15 & 20 & 52 & $\begin{array}{c}69,3 \\
3\end{array}$ & 8 & $\begin{array}{r}10 \\
67 \\
\end{array}$ \\
\hline 25 & $\begin{array}{l}\text { IV.3 } \\
5\end{array}$ & 0 & 0 & 27 & 33,33 & 48 & $\begin{array}{c}59,2 \\
6\end{array}$ & 6 & $\begin{array}{c}7,4 \\
1\end{array}$ \\
\hline 26 & $\begin{array}{l}\text { IV.3 } \\
6\end{array}$ & 16 & 16 & 54 & 54 & 26 & 26 & 4 & 4 \\
\hline \multicolumn{2}{|c|}{ Jumlah } & 36 & $1,7 c$ & 557 & 32,19 & 1127 & $\begin{array}{c}75,0 \\
7\end{array}$ & 224 & $\begin{array}{l}10, \\
98\end{array}$ \\
\hline
\end{tabular}

1. Siswa mendefinisikan berbagai istilah dalam memahami materi Sejarah Kebudayaan Islam.

2. Siswa menunjukkan contoh sesuai materi Sejarah Kebudayaan Islam.

3. Siswa menuliskan secara berurutan materi pada pembelajaran Sejarah Kebudayaan Islam.

4. Siswa menjelaskan materi pada pembelajaran Sejarah Kebudayaan Islam.

5. Siswa memberikan contoh sesuai dengan materi Sejarah Kebudayaan Islam yang telah disampaikan.

6. Siswa meringkas materi pembelajaran Sejarah Kebudayaan Islam.

7. Siswa mendemonstrasikan materi pembelajaran Sejarah Kebudayaan Islam.

8. Siswa menghubungkan materi Sejarah Kebudayaan Islam dengan kehidupan nyata.

9. Siswa merincikan materi pembelajaran Sejarah Kebudayaan Islam.

10. Siswa menguraikan kembali penjelasan guru pada materi Sejarah Kebudayaan Islam.

11. Siswa menyimpulkan materi pembelajaran Sejarah Kebudayaan Islam.

12. Siswa menulis kembali penjelasan pada materi Sejarah Kebudayaan Islam. 
13. Siswa meringkas kembali penjelasan guru tentang materi Sejarah Kebudayaan Islam.

Dari tabel di atas diketahui bahwa dari keseluruhan hasil observasi variabel $\mathrm{Y}$ adalah alternatif jawaban sangat baik $36(1,76 \%)$, alternatif jawaban baik $657(32,19 \%)$, alternatif jawaban cukup baik 1127 (55,07\%), dan alternatif jawaban tidak baik 224 (10,98\%), dengan jumlah total 2041 (100\%).

Sehingga $F=2041$, dan

$$
\begin{aligned}
\mathrm{N}= & \text { Jumlah Populasi } \mathrm{x} \text { Jumlah } \\
& \text { Aspek Yang Diobservasi } \mathrm{x} \\
& \text { Jumlah Observasi } \mathrm{x} \text { skor } \\
& \text { tertinggi } \\
= & 26 \times 13 \times 3 \times 4 \\
= & 4056
\end{aligned}
$$

Untuk mengetahui hasil belajar kognitif siswa pada mata pelajaran Sejarah Kebudayaan Islam di Madrasah Ibtidaiyah Nurul Jihad Kecamatan Tembilahan Hulu, digunakan rumus:

$\mathrm{F}$

$$
\begin{aligned}
\mathrm{P} & =\frac{-}{\mathrm{N}} \times 100 \% \\
\mathrm{P} & =\frac{2041}{4056} \times 100 \% \\
& =50,32 \%
\end{aligned}
$$

Dengan demikian dapat disimpulkan bahwa hasil belajar kognitif siswa pada mata pelajaran Sejarah Kebudayaan Islam di Madrasah Ibtidaiyah Nurul Jihad Kecamatan Tembilahan Hulu, mencapai angkai 50,32\%, dan dikategorikan cukup baik, karena angka $50,32 \%$ terletak pada interval $61 \%-80 \%$.
Untuk melakukan pembahasan terhadap data hasil penelitian ditempuh langkah-langkah sebagai berikut:

\section{Langkah Pertama:}

Membuat Ha dan Ho dalam bentuk kalimat di bawah ini:

Ha:Terdapat pengaruh yang positif dan signifikan antara komunikasi dalam pembelajaran terhadap hasil belajar kognitif pada mata pelajaran Sejarah Kebudayaan Islam di Madrasah Ibtidaiyah Nurul Jihad Kecamatan Tembilahan Hulu.

Ho :Tidak terdapat pengaruh yang positif dan signifikan antara komunikasi dalam pembelajaran terhadap hasil belajar kognitif pada mata pelajaran Sejarah Kebudayaan Islam di Madrasah Ibtidaiyah Nurul Jihad Kecamatan Tembilahan Hulu.

\section{Langkah Kedua:}

Membuat Ha dan Ho dalam bentuk statistik, yaitu:

$$
\begin{array}{ll}
\text { Ha: } & r \neq 0 \\
\text { Ho: } & r=0
\end{array}
$$

\section{Langkah ketiga:}

Membuat tabel penolong untuk menghitung angka statistik dengan cara sebagai berikut:

\section{Langkah Keempat:}

Mencari rata-rata variabel $\mathrm{X}$ dan ratarata variabel Y:

1. Rata-Rata Variabel $X$

$$
\text { Nilai } \bar{X}=
$$




$$
\begin{aligned}
& \mathrm{nx} \\
= & \frac{157}{1} \\
= & 157
\end{aligned}
$$

Dengan demikian diketahui bahwa rata-rata variabel $X=157$

2. Rata-Rata Variabel Y

$$
\begin{aligned}
\text { Nilai } \bar{Y}= & \frac{\sum Y}{\text { ny }} \\
& =\frac{2041}{26} \\
& =78,5
\end{aligned}
$$

Dengan demikian diketahui bahwa rata-rata variabel $\mathrm{Y}=78,5$

\section{Langkah Kelima}

Mencari varians $\left(\mathrm{S}^{2} \mathrm{X}-\mathrm{y}\right)$ dengan rumus:

$$
\begin{gathered}
S_{\mathrm{x}-\mathrm{y}}^{2}=\frac{\sum(\mathrm{X}-\overline{\mathrm{X}})^{2}+\sum(\mathrm{Y}-\overline{\mathrm{Y}})^{2}}{\left(\mathrm{n}_{\mathrm{x}}+\mathrm{n}_{\mathrm{y}}\right)-2} \\
S_{x-y}^{2} \\
=\frac{(157-157)^{2}+(2041-78,5)^{2}}{(1+26)-2} \\
S_{x-y}^{2}=\frac{0+(1962,5)^{2}}{25} \\
S_{x-y}^{2}=\frac{3851406,25}{25} \\
S_{x-y}^{2}=154056,25
\end{gathered}
$$

\section{Langkah Keenam}

Menentukan nilai deviasi pada distribusi dengan menggunakan rumus thitung:

$$
\begin{gathered}
t=\frac{\bar{X}-\bar{Y}}{\sqrt{S_{x-y}^{2}\left(\frac{1}{n_{x}}+\frac{1}{n_{y}}\right)}} \\
t=\frac{157-78,5}{\sqrt{154056,25\left(\frac{1}{1}+\frac{1}{26}\right)}} \\
t=\frac{78,5}{\sqrt{154056,25(1+0,038)}}
\end{gathered}
$$

$$
\begin{gathered}
\mathrm{t}=\frac{78,5}{\sqrt{154056,25(1,038)}} \\
\mathrm{t}=\frac{78,5}{\sqrt{159910,4}} \\
\mathrm{t}=\frac{78,5}{399,9} \\
\mathrm{t}=0,2
\end{gathered}
$$

\section{Langkah Ketujuh}

Membandingkan ttabel dan thitung. Sedangkan $\mathrm{t}$ tabel diperoleh dari df (derajat kebebasan) dengan rumus:

$$
\begin{aligned}
& \mathrm{df}=\mathrm{n} 1+\mathrm{n} 2-2 \\
& =1+26-2 \\
& =25
\end{aligned}
$$

Berdasarkan tabel $\mathrm{t}$, diketahui bahwa nilai untuk 25 adalah 1,708. Karena thitung $\leq \mathrm{t}$ tabel, maka Ho diterima, artinya tidak signifikan.

Karena thitung $\leq \mathrm{t}$ tabel, maka terima Ho dan tolak Ha. Dengan demikian tidak terdapat pengaruh yang positif dan signifikan antara komunikasi dalam pembelajaran terhadap hasil belajar kognitif pada mata pelajaran Sejarah Kebudayaan Islam di Madrasah Ibtidaiyah Nurul Jihad Kecamatan Tembilahan Hulu.

Dari data hasil observasi terhadap variabel $\mathrm{X}$ dapat dianalisa bahwa komunikasi dalam pembelajaran pada mata pelajaran Sejarah Kebudayaan Islam di Madrasah Ibtidaiyah Nurul Jihad Kecamatan Tembilahan Hulu, mencapai angka $72,69 \%$ dan dikategorikan baik, karena angka $72,69 \%$ terletak pada interval $61 \%$ $80 \%$.

Dari data hasil observasi terhadap variabel Y dapat dianalisa bahwa hasil belajar kognitif siswa pada mata pelajaran Sejarah Kebudayaan Islam di 
Madrasah Ibtidaiyah Nurul Jihad Kecamatan Tembilahan Hulu, mencapai angkai 50,32\%, dan dikategorikan cukup baik, karena angka $50,32 \%$ terletak pada interval $61 \%-80 \%$.

Dari data melalui observasi terhadap variabel $\mathrm{X}$ dan variabel $\mathrm{Y}$, dapat dianalisa bahwa tidak terdapat pengaruh yang positif dan signifikan antara komunikasi dalam pembelajaran terhadap hasil belajar kognitif pada mata pelajaran Sejarah Kebudayaan Islam di Madrasah Ibtidaiyah Nurul Jihad Kecamatan Tembilahan Hulu, yang ditunjukkan dengan angka 0,2 dan diinterpretasikan sangat rendah. Karena berdasarkan tabel $\mathrm{t}$, nilai untuk 25 adalah 1,708.

Sehingga thitung $\leq$ ttabel, artinya $0,2 \leq$ 1,708, maka Ho diterima, angka 0,2 terletak pada daerah penolakan, maka Ha ditolak dan Ho diterima.

\section{KESIMPULAN}

Dari hasil penelitian dapat disimpulkan sebagai berikut:

1. Komunikasi dalam pembelajaran pada mata pelajaran Sejarah Kebudayaan Islam di Madrasah Ibtidaiyah Nurul Jihad Kecamatan Tembilahan Hulu, mencapai angka $72,69 \%$ dan dikategorikan baik, karena angka $72,69 \%$ terletak pada interval $61 \%-80 \%$.

2. Hasil belajar kognitif siswa pada mata pelajaran Sejarah Kebudayaan Islam di Madrasah Ibtidaiyah Nurul Jihad Kecamatan Tembilahan Hulu, mencapai angkai 50,32\%, dan dikategorikan cukup baik, karena angka 50,32\% terletak pada interval $61 \%-80 \%$.

3. Melalui analisa data terhadap kedua variabel di atas didapat hasil tHitung < tTabel, maka Ho diterima dan Ha ditolak. Dengan demikian tidak terdapat pengaruh yang positif dan signifikan antara komunikasi dalam pembelajaran terhadap hasil belajar kognitif pada mata pelajaran Sejarah Kebudayaan Islam di Madrasah Ibtidaiyah Nurul Jihad Kecamatan Tembilahan Hulu, yang ditunjukkan dengan angka 0,2 dan diinterpretasikan sangat rendah. Karena berdasarkan tabel t, nilai untuk 25 adalah 1,708. Sehingga thitung $\leq$ ttabel, artinya $0,2 \leq$ 1,708, maka Ho diterima, angka 0,2 terletak pada daerah penolakan, maka Ha ditolak dan Ho diterima.

\section{REFERENSI}

Abu Ahmadi. (2004). Psikologi Belajar. Jakarta: Rineka Cipta.

Ahmad Azhari. (2001). Supervisi Rencana Program Pembelajaran. Jakarta: Riau Putra.

Anas Sudijono, (2008), Pengantar Statistik Pendidikan, Jakarta: Raja Grafindo Persada.

Arief S. Sadiman. (2006). Media Pendidikan. Jakarta: Rajawali Pers.

Burhan Bungin, (2010), Metodologi Penelitian Kuantitatif, Jakarta: Prenada Media Group.

Cholid Narbuko dan Abu Ahmad, (2005), Metodologi Penelitian, Jakarta: Bumi Aksara.

Dariyanto. (1995). Evaluasi Pendidikan. Jakarta: Bumi Aksara. 
Deddy Yusuf Yudhyarta. (2011). Modul Organisasi dan Manajemen. Tembilahan: STAI Auliaurrasyidin.

Departemen Pendidikan Nasional. (2008). Kamus Besar Bahasa Indonesia Pusat Bahasa. Jakarta: Gramedia Pustaka Utama.

Dimyati dan Moedjiono. (1999). Teori Belajar dan Pembelajaran. Jakarta: Gramedia.

Hasbullah. (2004). Dasar-dasar Ilmu Pendidikan. Jakarta: Rajawali Pers.

Iskandar, (2010), Metodologi Penelitian Pendidikan, Jakarta: Gaung Persada Press.

M. Musfiqon. (2012). Panduan Lengkap Metodologi Penelitian Pendidikan. Jakarta: Prestasi Pustakaraya.

M. Sobry Sutikno. (2009). Belajar dan Pembelajaran; Upaya Kreatif dalam Mewujudkan Pembelajaran yang Berhasil. Bandung: Prospect. . (2008). Interaksi dan Motivasi Belajar Mengajar. Jakarta: Rajawali Press.

(2004). Model Pembelajaran Interaksi Sosial, Pembelajaran Efektif dan Retorika. Mataram: NTP Press.

Martinis Yamin. (2012). Strategi Pembelajaran Berbasis Kompetensi. Jakarta: Gung Persada Press.

Muhibbin Syah. (2004). Psikologi Belajar dengan Pendekatan Baru. Jakarta: Grafindo Persada.

Nana Sudjana. (2000). Dasar-Dasar Proses Belajar Mengajar. Bandung: Sinar Baru Algesindo.

Nasution. (2000). Berbagai Pendekatan Dalam Proses Belajar dan Mengajar. Jakarta: Bumi Aksara.

Oemar Hamalik. (2001). Kurikulum dan Pembelajaran. Jakarta: Bumi Aksara.

Riduwan. (2002). Skala Pengukuran Variabel-Variabel Penelitian. Bandung: Alfabeta.
. (2010). Dasar-Dasar Statistika. Bandung: Alfabeta.

Sarlito Wirawan. (2006). Pengantar Umum Psikologi. Jakarta: Bulan Bintang.

Sukardi. (2005). Metodologi Penelitian Pendidikan. Jakarta: Bumi Aksara.

Thohirin. (2005). Psikologi Pembelajaran Pendidikan Agama Islam. Jakarta: Rajawali Pers.

Wina Sanjaya. (2008). Kurikulum dan Pembelajaran. Jakarta: Prenada Media Group.

Yuhara Sukra. (2004). Pedoman Perbaikan Pendidikan. Jakarta: UI Press.

Yusri Arryza. (2002). Kemampuan Aspek Kognitif, Afektif dan Psikomotor. Bandung: Remaja Rosdakarya. 